\title{
Article \\ Bioactivity Potential of Industrial Sunflower Meal Ethanol-Wash Solute Obtained as Waste from Protein Isolation Process
}

\author{
Petya Ivanova $^{1}(\mathbb{D})$, Ivan G. Ivanov ${ }^{2}$ (D), Yulian Tumbarski ${ }^{3}$, Hristo Kalaydzhiev ${ }^{4}$, Ivayla N. Dincheva ${ }^{5}$ \\ and Vesela I. Chalova ${ }^{1, *(D)}$
}

check for

updates

Citation: Ivanova, P.; Ivanov, I.G.; Tumbarski, Y.; Kalaydzhiev, H.; Dincheva, I.N.; Chalova, V.I.

Bioactivity Potential of Industrial Sunflower Meal Ethanol-Wash Solute Obtained as Waste from Protein Isolation Process. Appl. Sci. 2021, 11, 11007. https://doi.org/10.3390/ app112211007

Academic Editor: Ana Oliveira

Received: 26 October 2021

Accepted: 18 November 2021

Published: 20 November 2021

Publisher's Note: MDPI stays neutral with regard to jurisdictional claims in published maps and institutional affiliations.

Copyright: (c) 2021 by the authors. Licensee MDPI, Basel, Switzerland. This article is an open access article distributed under the terms and conditions of the Creative Commons Attribution (CC BY) license (https:/ / creativecommons.org/licenses/by/ $4.0 /)$.
1 Department of Biochemistry and Molecular Biology, University of Food Technologies, 26 Maritsa Blvd., 4002 Plovdiv, Bulgaria; petia_ivanova_georgieva@abv.bg

2 Department of Organic Chemistry and Inorganic Chemistry, University of Food Technologies, 26 Maritsa Blvd., 4002 Plovdiv, Bulgaria; ivanov_ivan.1979@yahoo.com

3 Department of Microbiology, University of Food Technologies, 26 Maritsa Blvd., 4002 Plovdiv, Bulgaria; tumbarski@abv.bg

4 Department of Analytical Chemistry and Physical Chemistry, University of Food Technologies, 26 Maritsa Blvd., 4002 Plovdiv, Bulgaria; hristo.kalaydzhiev@yahoo.com

5 AgroBioInstitute, Agricultural Academy, 8 Dragan Tsankov Blvd., 1164 Sofia, Bulgaria; ivadincheva@yahoo.com

* Correspondence: veselachalova@gmail.com

Featured Application: Sunflower meal ethanol-wash solute (SEWS) was obtained as waste by pretreatment of industrial sunflower meal, used as a material for protein isolation. The biochemical characterization and bioactive properties, established in the current study, turned it into a valuable product for the agriculture, food, and nutraceutical industries. Potential applicability of SEWS could lead to more complete utilization of sunflower meal and add value to the primary product of sunflower seed processing, namely sunflower oil.

Abstract: Industrial sunflower meal is rich in secondary metabolites, which negatively influence the quality and functional properties of respective protein isolates. To reduce their quantity, sunflower meal was subjected to a four-step treatment with $75 \%$ aqueous ethanol solution. The ethanol-wash liquids were collected, concentrated, and freeze-dried to prepare powdery sunflower meal ethanolwash solute (SEWS). Otherwise considered waste from the main process of protein isolation, the SWES was turned into a novel product containing macrocomponents, microelements, and bioactive compounds. It was found to be rich in carbohydrates $(62.14 \%)$, lipids $(7.73 \%)$, and bioactive compounds such as phenols (16.38\%) and flavonoids (4.41\%). Gas Chromatography-Mass Spectrometry (GC-MS) analyzes revealed prevalence of sucrose (14.01\%), linoleic acid (12.10\%), and chlorogenic acid $(85.41 \%)$ based on total ion current (TIC) of polar, nonpolar, and phenolic compounds, respectively. The SEWS was found to be rich in microelements with iron $(259.02 \mathrm{mg} / \mathrm{kg})$ and copper $(109.36 \mathrm{mg} / \mathrm{kg}$ ) being the highest amounts. The product contained $0.10 \mathrm{mg} / \mathrm{kg}$ selenium. Scavenging of 2,2-diphenyl-1-picrylhydrazyl (DPPH) radicals increased with the increase in SEWS concentrations and reached $52.3 \%$ and $69 \%$ for $0.05 \%$ SEWS when dissolved in water and $70 \%$ ethanol, respectively. The highest hydroxyl radical scavenging activity (52.4\%) was achieved at $0.1 \%$ SEWS. For all studied concentrations $(0.005 \%$ to $0.1 \%)$, the SEWS exhibited a higher inhibition capacity than mannitol, which was used as a positive control. The SEWS demonstrated inhibiting properties against Gram (+) Curtobacterium flaccumfaciens PM-YT and Fusarium moniliforme ATCC 38932 fungus. The obtained results outline the SEWS as a natural product with bioactive properties that might be useful in the agriculture, food, and nutraceutical industries.

Keywords: sunflower meal; ethanol-wash solute; antioxidant activities; antimicrobial activities; GC-MS analysis 


\section{Introduction}

Sunflower (Helianthus annuus L.) is an economically important oil-bearing plant [1,2]. Sunflower seeds are mainly used for the production of vegetable oil. The process includes the generation of sunflower meal as a by-product in quantities that approximate $36 \%$ of the weight of the processed seeds [3]. Currently, sunflower meal is used as a proteinrich ingredient in feed formulation. The application of this byproduct in animal nutrition, however, is limited by the presence of some anti-nutrients [4] and poorly digestible fibers [5]. Alternatively, sunflower meal can be used for human consumption by either direct inclusion as an ingredient of food products [6] or after transformation into value-added compounds such as proteins, antioxidants, phytochemicals, and dietary fiber [7]. The efficient utilization of byproducts or food processing organic waste is emerging as a rapidly developing economically and socially important sector of human life in response to the worldwide need for efficient utilization of natural resources and gentle care to the environment [4].

In recent years, there has been an increasing interest in sunflower meal protein isolates as an alternative to animal proteins currently used in the food industry [6]. They have high nutritive quality and attractive functional characteristics. A major challenge to the preparation of these products is the presence of phenols that may remain inbound in the final product and negatively affect their color, taste, and functionality. According to Liu et al. [8], pre-treatment of the meal aiming at reduction of anti-nutrients such as phenols may improve the quality of the oil-bearing meal-derived protein isolates. Being focused on the biorefinery of rapeseed and sunflower meals, Laguna et al. [9] demonstrated that for extracting phenols, mixtures of water and ethanol could be efficiently used instead of methanol. Kalaydzhiev et al. [10] achieved a 4-fold reduction of phenols in industrial rapeseed meal after pre-treatment of the byproduct with $75 \%$ aqueous ethanol solution before using it as a source for preparation of protein isolates with enhanced solubility [11]. To increase the profitability and usability of the rapeseed meal, the ethanol-wash liquids were collected, vacuum-concentrated, and lyophilized. The resulting powder exhibited bioactive capacity, including antioxidant and antifungal activity, which outlined it as a prospective agent for food biopreservation or plant bioprotection [12].

Following a similar approach, a powdery sunflower meal ethanol-wash solute (SEWS), remaining as a waste of the main process of protein isolation from sunflower meal, was prepared in our laboratory [13]. The SEWS appeared as a surfactant with good solubility in water. The current research is a continuation of the previous one aiming at the further evaluation of SEWS' applicability potential. The phytochemical profile, antioxidant and antimicrobial capacity of the SEWS were investigated to evaluate its suitability in agriculture, food, or nutraceutical industries.

\section{Materials and Methods}

\subsection{Preparation of Sunflower Meal Ethanol Wash Solute (SEWS)}

Industrial sunflower meal was obtained from a local company. It was ground and sifted, and uniform particles sizing less than $0.315 \mathrm{~mm}$ were used to prepare SEWS. The procedure was schematically outlined by Gandova et al. [13]. Briefly, sunflower meal was treated with 75\% aqueous ethanol solution 4 times. The washing liquids from each step were collected, vacuum-concentrated (RV 3 V Rotary Evaporator, IKA ${ }^{\circledR}$-Werke GmbH \& Co. KG, Staufen, Germany) at $50{ }^{\circ} \mathrm{C}$ for ethanol evaporation, and freeze-dried (Lyovac GT2, Leybold-Heraeus, Burladingen, Germany) to obtain powdery SEWS. The ethanol-treated sunflower meal, remaining as a residue, served as a source for the preparation of protein isolates which, however, was not a subject of this investigation.

\subsection{Chemical Analyzes}

Total carbohydrates were quantified by Dubois et al. [14], while the evaluation of glucose was performed by using a specific glucose oxidase-peroxidase enzymatic system [15]. Total lipids and proteins were analyzed by Bligh and Dyer [16] and Bradford [17], respectively. Bovine serum albumin was used for the standard curve needed for the quantification 
of the protein. Ash content was determined by ICC Standard No. 104/1 [18]. Total phenols and flavonoids were evaluated as described by Petkova et al. [19] and Kivrak et al. [20]. Calculations were made by using standard curves prepared with gallic acid and quercetin, respectively. Selenium (Se) was determined by using inductively coupled plasma optical emission spectrometry (ICP-OES) [21]. For all other microelements and heavy metals, a Bulgarian National Standard procedure (BDS) was used [22]. Results were calculated on a dry matter basis, $91.55 \pm 0.49 \%$, unless otherwise specified.

\subsection{Gas Chromatography-Mass Spectrometry (GC-MS) Analyzes of SEWS}

GC-MS was used to analyze three major groups of phytochemicals, namely polar, nonpolar, and phenolic compounds, differing by their physicochemical characteristics. The polar and nonpolar metabolites were extracted as described by Roessner et al. [23]. The extraction of phenolic acids was conducted as described by Georgiev et al. [12]. GC-MS analyses were carried out on gas chromatograph Agilent Technology Hewlett Packard 7890 A, coupled with mass detector Agilent Technology 5975 inert XL EI/CI MSD at $70 \mathrm{eV}$ ). Separation of polar and polyphenol compounds was done using an HP-5MS column $(30 \mathrm{~m} \times 0.25 \mathrm{~mm} \times 0.25 \mu \mathrm{m})$ by using the following temperature program: from 100 to $180{ }^{\circ} \mathrm{C}$ with a step of $15{ }^{\circ} \mathrm{C} / \mathrm{min}$ and from 180 to $300{ }^{\circ} \mathrm{C}$ with a step of $5^{\circ} \mathrm{C} / \mathrm{min}$, then hold on $300{ }^{\circ} \mathrm{C}$ for $10 \mathrm{~min}$. An injector temperature of $250{ }^{\circ} \mathrm{C}$ and a flow rate of carrier gas (helium) $1.0 \mathrm{~mL} / \mathrm{min}$ were used. Injection volume was $1 \mu \mathrm{L}$ and split ratio 10:1. The separation of nonpolar compounds was performed as follows: $70{ }^{\circ} \mathrm{C}$ for $1 \mathrm{~min}$, then $5{ }^{\circ} \mathrm{C} / \mathrm{min}$ to $310{ }^{\circ} \mathrm{C}$ for $10 \mathrm{~min}$; run time $-59 \mathrm{~min}$.

The obtained mass spectra were read using a 2.64 Automated Mass Spectral Deconvolution and Identification System (AMDIS, NIST, Gaithersburg, MD, USA). The separated compounds were identified by comparison of their GC-MS spectra and Kovach retention index (RI) with referent compounds in the NIST 08 database (NIST Mass Spectral Database, PC-Version 5.0, 2008) - National Institute of Standardization and Technology (Gaithersburg, MD, USA). The RIs of compounds were recorded with a standard n-hydrocarbon calibration mixture (C9-C36, Restek, Teknokroma, Spain) using AMDIS software, version 2.64 (National Institute of Standardization and Technology (NIST), Gaithersburg, MD, USA).

\subsection{Determination of Antioxidant Activity}

The antioxidant capacity of SEWS was evaluated in water (SEWS-W) and 70\% ethanol (SEWS-E) by three methods differing by their principle. The study was conducted with SEWS in different concentrations (varying from 0.005 to $0.1 \%$ ).

The scavenging effect of SEWS on 2,2-diphenyl-1-picrylhydrazyl (DPPH) radical was estimated by reduced absorbance of the reagent after SEWS addition. Experimental details are described by Georgiev et al. [12]. The absorbance $\left(\mathrm{A}_{\text {sample }}\right)$ of the DPPH-SEWS mixture was measured at $517 \mathrm{~nm}$ with a spectrophotometer (Spekol 11; Carl Zeiss Jena, Jena, Germany) after $30 \mathrm{~min}$ in darkness. The antiradical activity (AA) was calculated by the formula $\left.\mathrm{AA}=\left(\mathrm{A}_{\text {control }}-\mathrm{A}_{\text {sample }}\right) / \mathrm{A}_{\text {control }}\right)$ and multiplied by 100 to express in percentage. The control was treated as the corresponding sample but without the addition of SEWS. The synthetic antioxidant butylhydroxytoluene (BHT) was used as a positive control.

Ferric reducing antioxidant power (FRAP) assay was performed as described by Ivanov et al. [24]. Briefly, a $3 \mathrm{~mL}$ freshly prepared FRAP reagent [12] was mixed with $0.1 \mathrm{~mL} 0.1 \%$ SEWS prepared either in water or $70 \%$ aqueous ethanol solution. The mixture was maintained in dark for $10 \mathrm{~min}$ and the absorbance was measured at $593 \mathrm{~nm}$ against blank prepared with water or $70 \%$ ethanol. A standard curve was built with $\mathrm{FeSO}_{4} \cdot 7 \mathrm{H}_{2} \mathrm{O}$. The results of the FRAP analysis were expressed as $\mu \mathrm{mol} \mathrm{Fe} e^{2+}$ equivalents per gram dry weight SEWS [25].

Hydroxyl radical scavenging activity of SEWS was evaluated only in water (SEWS$\mathrm{W})$ due to interference of ethanol with the assay. The experiments were performed as before [12]. Mannitol, a classical OH• scavenger, was used as a positive control [26-28]. 


\subsection{Determination of Antimicrobial Activity}

\subsubsection{Test Microorganisms and Culture Media}

Antimicrobial activity of the SEWS was evaluated against 17 test microorganisms including eight Gram-positive bacteria (Bacillus subtilis ATCC 6633, Bacillus cereus, Bacillus amyloliquefaciens 4BCL-YT, Staphylococcus aureus ATCC 25923, Listeria monocytogenes ATCC 8632, Enterococcus faecalis, Micrococcus luteus 2YC-YT, Curtobacterium flaccumfaciens PM-YT), four Gram-negative bacteria (Salmonella enteritidis, Escherichia coli ATCC 8739, Proteus vulgaris ATCC 6380, Pseudomonas aeruginosa ATCC 9027), and five fungi (Candida albicans NBIMCC 74, Saccharomyces cerevisiae, Aspergillus niger ATCC 1015, Aspergillus flavus, Fusarium moniliforme ATCC 38932). Luria-Bertani agar supplemented with glucose (LBG agar) and malt extract agar (MEA) media were used for cultivation of test microorganisms and implementation of agar-well diffusion assay. Both culture media were prepared as per the manufacturer's instructions.

\subsubsection{Antimicrobial Assay}

The antimicrobial activity of SEWS was determined by the agar-well diffusion method as previously described [29]. Briefly, the pathogenic bacteria and Candida albicans NBIMCC 74 were cultured on LBG agar medium at $37^{\circ} \mathrm{C}$ for $24 \mathrm{~h}$, while Bacillus subtilis ATCC 6633, B.cereus, B. amyloliquefaciens 4BCL-YT, Micrococcus luteus 2YC-YT, and Curtobacterium flaccumfaciens PM-YT were cultured on LBG agar medium at $30{ }^{\circ} \mathrm{C}$ for $24 \mathrm{~h}$. Candida albicans NBIMCC 74 and Saccharomyces cerevisiae were grown on MEA at $30^{\circ} \mathrm{C}$ for $24 \mathrm{~h}$. The remaining fungi were grown at $30{ }^{\circ} \mathrm{C}$ for 7 days or until sporulation. The inocula of bacteria were prepared by homogenization of a small amount of biomass in $5 \mathrm{~mL}$ of sterile $0.5 \% \mathrm{NaCl}$. The inocula of fungi were prepared by the addition of $5 \mathrm{~mL}$ of sterile $0.5 \% \mathrm{NaCl}$ into the tubes. After vigorous shaking, they were filtered and replaced in other tubes before use. The number of cells and fungal spores was determined by using a bacterial counting chamber (Thoma, Poly-Optik GmbH, Bad Blankenburg, Germany). Their final concentrations were adjusted to $10^{8} \mathrm{CFU} / \mathrm{mL}$ for microbial cells and $10^{5} \mathrm{CFU} / \mathrm{mL}$ for fungal spores and subsequently inoculated in preliminarily melted and tempered at $45-48^{\circ} \mathrm{C}$ agar media. Aliquots of $17 \mathrm{~mL}$ inoculated media were transferred to sterile Petri plates ( $\mathrm{d}=90 \mathrm{~mm}$; Gosselin ${ }^{\mathrm{TM}}$, Hazebrouck, France) and allowed to solidify. Then, six wells $(\mathrm{d}=6 \mathrm{~mm})$ per plate were cut.

The SEWS was dissolved in distilled water at a concentration of $5 \mathrm{mg} / \mathrm{mL}$ followed by serial 2 -fold dilutions. Aliquots of $60 \mu \mathrm{L}$ of each sample were pipetted into the agar wells in triplicates. Antimicrobial activity was detected by measuring the zone of inhibition (including the wells diameter, $\mathrm{mm}$ ) that appeared after incubation for $48 \mathrm{~h}$ at temperatures specified above. Ampicillin $(10 \mu \mathrm{g} / \mathrm{mL})$ and nystatin $(40 \mu \mathrm{g} / \mathrm{mL})$ were used as positive controls. Distilled water was used as a negative control. The minimum inhibitory concentration (MIC) was considered as the lowest concentration of SEWS, which inhibited the growth of the respective microorganisms [30].

\subsection{Statistical Analyzes}

Presented data are the mean \pm standard deviation (SD) of three independent experiments $(\mathrm{n}=3)$. Data were analyzed by one-way analysis of variance (ANOVA) using Statgraphics Centurion statistical program (version XVI, 2009) (Stat Point Technologies, Ins., Warrenton, VA, USA). Mean differences were established by Tukey's honestly significant difference (HSD) test. Statistical differences were considered significant at $p<0.05$.

\section{Results and Discussion}

\subsection{Preparation and Chemical Characterization of SEWS}

The SEWS was obtained as waste from the main process of sunflower meal protein isolation [13] and was not optimized for the content of any of the analyzed compounds. Its potential as a value-added product was evaluated to maximize the use of the sunflower 
meal as a byproduct and enhance the sustainability of vegetable oil production for both food and technical purposes [31,32].

Proximate analyzes revealed that more than $50 \%$ of the SEWS consisted of carbohydrates $(62.14 \%$, Table 1$)$. This result is justified by the polar nature of ethanol used for the preparation of the product. By using ethanol as a solvent, Baümler et al. [33] extracted over $75 \%$ of the initial sugar content of sunflower collets. Low molecular weight carbohydrates, simple sugars, di- and oligosaccharides, are well soluble in aqueous ethanol solutions [34] and their presence in the SEWS was expected.

Table 1. Chemical composition of sunflower meal ethanol-wash solute.

\begin{tabular}{cc}
\hline Component & Content, \% \\
\hline Total carbohydrates & $62.14 \pm 2.87$ \\
Glucose & $3.18 \pm 0.09$ \\
Total lipids & $7.73 \pm 0.18$ \\
Protein & $1.99 \pm 0.08$ \\
Ash & $6.33 \pm 0.16$ \\
Total phenols & $16.38 \pm 0.55$ \\
Total flavonoids & $4.41 \pm 0.17$ \\
\hline
\end{tabular}

Indeed, GC-MS analyzes of the polar compounds in SEWS demonstrated a prevalence of sucrose having the highest total ion current (TIC) in this group (14.01\%, Table 2). High TICs, $6.66 \%, 5.86 \%$, and $5.41 \%$, were observed for galactose, fructose, and glucose, respectively (Table 2). The presence of $3.18 \%$ glucose in the SEWS was estimated by a highly specific enzymatic method (Table 1). A similar carbohydrate profile of ethanolic extract from sunflower collets was reported by Baümler et al. [33]. Interestingly, in the current study, melibiose was the compound having the second-highest TIC $(9.93 \%)$ after sucrose (Table 2). Although this saccharide is not typical for sunflower meal, its appearance in the SEWS may be a result of the degradation of raffinose, stachyose, or verbascose during seed processing [35]. Simple sugars and disaccharides are readily used as carbon and energy sources for microbial growth [36-38]. While most wild-type microorganisms consume glucose preferentially to other carbohydrates, the progress of DNA recombinant technology allowed the development of strains capable of co-utilization of biomass-derived mixed sugars $[39,40]$. Therefore, consisting of $62.14 \%$ carbohydrates (Table 1 ), the SWES might be potentially useful as a carbon source for microbial growth in biotechnology.

Sugar alcohols are a group of polar compounds in the SEWS having relatively high TICs (\%) (Table 2). Among them, glucitol, glycerol, arabitol, and xylitol exhibited 5.34\%, $4.77 \%, 4.11 \%$, and $3.24 \%$ TIC, respectively (Table 2). Recently, sugar alcohols gained increasing interest due to their suitability to replace sugar in antidiabetic treatment and healthy lifestyle living [41]. They are constituents of sugar-free food products, including ice cream, spreads, and bakery goods [42]. The polyols have relatively high sweetness compared to sucrose but do not enhance plasma glucose due to specifics in their degradation and subsequent assimilation [43]. They are also used as softeners and crystallization inhibitors in the food industry [44] or valuable compounds in oral and dental care products [45].

Sunflower meal, obtained after solvent extraction, contains approximately $3 \%$ residual oil [6]. The four-fold treatment of the sunflower meal, used in the current study, resulted in the enhancement of the lipid content in SEWS to $7.73 \%$ (Table 1). It is most probably due to the higher polarity of the ethanol compared to hexane, leading to higher extraction efficiency [46]. Baümler et al. [33] and Rodriguez et al. [47] demonstrated the feasibility of using ethanol as an alternative solvent to hexane in the oil extraction from sunflower collets, regardless of the low selectivity of the reagent and the relatively high amount of non-lipid compounds in the extracted material. Recently, there has been an escalating interest in ethanol as a "green" extracting agent of vegetable oil due to its low toxicity and handling risks $[33,46,47]$. GC-MS analyzes demonstrated a prevalence of linoleic $(12.10 \%$ TIC) and palmitic acids ( $6.18 \%$ TIC) followed by arachidic $(4.86 \%$ TIC) and stearic $(4.30 \%$ TIC) acids 
(Table 2). The four of them are typical constituents of sunflower oil [48]. While the latter three are saturated fatty acids, the linoleic one, which has the highest TIC value in the group of nonpolar compounds (Table 2), is unsaturated and considered beneficial for human health and disease prevention [49]. In addition, unsaturated fatty acids, particularly the linoleic one, were demonstrated to be valuable for technical purposes, such as corrosion inhibition and treatment of cellulosic fabrics $[50,51]$.

Table 2. Polar (A), nonpolar (B) and phenolic (C) compounds in sunflower meal ethanol-wash solute identified by GC-MS analysis.

\begin{tabular}{|c|c|c|c|c|}
\hline \multicolumn{2}{|r|}{ Compound } & RT & RI & TIC, $\%$ \\
\hline \multicolumn{5}{|c|}{ A: Polar compounds } \\
\hline \multicolumn{5}{|c|}{ Amino acids } \\
\hline 1 & Alanine & 4.69 & 1097 & 0.64 \\
\hline 2 & Valine & 4.90 & 1208 & 0.78 \\
\hline 3 & Leucine & 6.03 & 1266 & 1.16 \\
\hline 4 & Isoleucine & 6.23 & 1285 & 1.40 \\
\hline 5 & Proline & 6.30 & 1293 & 0.97 \\
\hline 6 & Glycine & 6.35 & 1299 & 0.84 \\
\hline 7 & Serine & 6.65 & 1351 & 0.39 \\
\hline 8 & Threonine & 6.78 & 1376 & 0.70 \\
\hline 9 & Aspartic acid & 8.19 & 1509 & 1.52 \\
\hline 10 & Methionine & 8.27 & 1512 & 0.45 \\
\hline 11 & Glutamic acid & 10.60 & 1608 & 1.43 \\
\hline 12 & Phenylalanine & 10.68 & 1635 & 0.89 \\
\hline 13 & Asparagine & 10.74 & 1659 & 0.26 \\
\hline 14 & Glutamine & 1160 & 1765 & 1.30 \\
\hline 15 & Lysine & 13.38 & 1911 & 0.75 \\
\hline 16 & Tyrosine & 13.52 & 1930 & 0.21 \\
\hline 17 & Histidine & 19.55 & 2145 & 0.39 \\
\hline \multicolumn{5}{|c|}{ Organic acids } \\
\hline 18 & Succinic acid & 6.40 & 1305 & 1.12 \\
\hline 19 & Fumaric acid & 6.61 & 1344 & 0.49 \\
\hline 20 & Malic acid & 8.00 & 1477 & 0.86 \\
\hline 21 & Pyroglutamic acid & 8.88 & 1518 & 4.31 \\
\hline \multicolumn{5}{|c|}{ Sugar acids and alcohols } \\
\hline 22 & Glycerol & 5.95 & 1264 & 4.77 \\
\hline 23 & Glyceric acid & 6.52 & 1341 & 3.01 \\
\hline 24 & Threitol & 8.61 & 1488 & 1.35 \\
\hline 25 & Erythreol & 9.03 & 1493 & 0.37 \\
\hline 26 & Threonic acid & 10.55 & 1569 & 1.48 \\
\hline 27 & Xylitol & 10.80 & 1690 & 3.24 \\
\hline 28 & Arabitol & 10.89 & 1699 & 4.11 \\
\hline 29 & Ribonic acid & 11.67 & 1822 & 2.17 \\
\hline 30 & Glucitol & 14.92 & 1942 & 5.34 \\
\hline 31 & Dulcitol & 15.15 & 1961 & 2.31 \\
\hline 32 & Gluconic acid & 16.04 & 1996 & 0.86 \\
\hline 33 & Myo-inositol & 16.64 & 2090 & 2.18 \\
\hline 34 & Galactinol & 28.72 & 2951 & 1.80 \\
\hline \multicolumn{5}{|c|}{ Saccharides (mono-, di-) } \\
\hline 35 & Xylose & 10.60 & 1661 & 1.05 \\
\hline 36 & Arabinose & 10.68 & 1673 & 1.82 \\
\hline 37 & Fructose & 12.03 & 1856 & 5.86 \\
\hline 38 & Galactose & 14.57 & 1876 & 6.66 \\
\hline 39 & Glucose & 14.62 & 1881 & 5.41 \\
\hline 40 & Sucrose & 23.69 & 2620 & 14.01 \\
\hline 41 & Melibiose & 25.36 & 2846 & 9.93 \\
\hline
\end{tabular}


Table 2. Cont.

\begin{tabular}{|c|c|c|c|c|}
\hline \multicolumn{2}{|c|}{ Compound } & RT & RI & TIC, \% \\
\hline \multicolumn{5}{|c|}{ B: Nonpolar compounds } \\
\hline \multicolumn{5}{|c|}{ Fatty acids } \\
\hline 1 & Myristic acid & 12.60 & 1837 & 0.84 \\
\hline 2 & Palmitoleic acid & 15.34 & 1905 & 0.30 \\
\hline 3 & Palmitelaidic acid & 15.44 & 1912 & 0.73 \\
\hline 4 & Palmitic acid & 15.79 & 1926 & 6.18 \\
\hline 5 & Linoleic acid & 18.63 & 2096 & 12.10 \\
\hline 6 & Oleic acid & 18.71 & 2099 & 0.14 \\
\hline 7 & Linolenic acid & 18.79 & 2102 & 1.72 \\
\hline 8 & Stearic acid & 19.07 & 2247 & 4.30 \\
\hline 9 & Arachidic acid & 20.65 & 2311 & 4.86 \\
\hline \multicolumn{5}{|c|}{ Alkenes } \\
\hline 10 & n-Eicosane & 17.01 & 2000 & 0.42 \\
\hline 11 & n-Tricosane & 20.31 & 2300 & 2.11 \\
\hline \multicolumn{5}{|c|}{ C: Phenolic compounds } \\
\hline 1 & Salicylic acid & 8.60 & 1510 & 0.64 \\
\hline 2 & Cinnamic acid & 8.91 & 1557 & 3.23 \\
\hline 3 & $\begin{array}{l}\mathrm{p}^{-} \\
\text {Hydroxybenzoic } \\
\text { acid }\end{array}$ & 10.46 & 1642 & 2.76 \\
\hline 4 & Vanillic acid & 11.18 & 1775 & 0.63 \\
\hline 5 & Syringic acid & 14.10 & 1884 & 1.85 \\
\hline 6 & Ferulic acid & 16.01 & 2103 & 0.90 \\
\hline 7 & Caffeic acid & 17.55 & 2140 & 0.81 \\
\hline 8 & Sinapic acid & 19.21 & 2253 & 0.74 \\
\hline 9 & Chlorogenic acid & 31.80 & 3111 & 85.41 \\
\hline
\end{tabular}

RT: Retention Time. RI: Kovach Retention Index. TIC: Total Ion Current.

The SEWS contained protein but in a relatively low amount (1.99\%, Table 1). Most probably, they belonged to the group of prolamins that are ethanol-soluble. Compared to albumins and globulins, the prolamins are in minor quantity in sunflower kernels [52]. The GC-MS analyses demonstrated the presence of both essential and non-essential amino acids (Table 2). Of all essential amino acids, leucine and isoleucine had the highest TICs $-1.16 \%$, and $1.40 \%$, respectively. Together with valine, they belong to the so-called branched amino acids, which were found to have a beneficial effect against numerous physiological disorders, such as liver cirrhosis, sepsis, trauma, or burn injury [53]. The same author indicated their potential usefulness in wound healing, attenuation of fatigue, and insulin production. Although not a major source of amino acids, the SEWS might be used as a dietary supplement where enhanced amounts of the branched amino acids are needed.

The SEWS contained a high amount of phenols (16.38\%, Table 1). Chlorogenic acid ( $85.41 \%$ TIC) was in the highest relevant amount, followed by cinnamic (3.23\% TIC) and p-hydroxybenzoic $(2.76 \%)$ acids (Table 2$)$. Syringic, ferulic, and caffeic acids were also established (Table 2). Taha et al. [54] also demonstrated that sunflower meal is a suitable source of phenols (with chlorogenic acid being in the highest amount). The highest yield of the latter was obtained by using acetone, but $60 \%$ ethanol was recommended for the extraction of chlorogenic acid if used in the food or pharmaceutical industries. A high amount of phenols (13.38\%) was established in the ethanol-wash solute prepared from industrial rapeseed meal [16], although with a difference in the relative composition of the phenolic acids compared to those in the SEWS. Laguna et al. [55] obtained single phenolic compounds after enzymatic treatment of dry alcoholic extracts prepared from rapeseed and sunflower meals. While not desired as a part of the protein isolates [56], these phytochemicals are valuable for their antioxidant, antimicrobial, and anticarcinogenic properties $[54,57]$. More specifically, chlorogenic acid was demonstrated to exert a beneficial 
effect on glucose and lipid metabolism [58] and promote wound healing by regulating the activity of metalloproteinases [59].

Compared to the ethanol-wash solute, obtained from rapeseed meal [12], the SEWS contained more than a 2.5 -fold higher amount of total flavonoids (Table 1). The flavonoids are plant secondary metabolites with powerful antioxidant activity having the capacity to reduce the oxidation of biomolecules [1]. Therefore, flavonoid fractions or flavonoid-rich products, such as SEWS, could be potentially used as additives in the food industry for enhancement of food quality and shelf life or as a dietary supplementation contributing to the overall improvement of the health status of humans.

The SEWS contained valuable microelements (Table 3$)$. The contents of iron $(259.02 \mathrm{mg} / \mathrm{kg}$ ) and copper $(109.36 \mathrm{mg} / \mathrm{kg}$ ) were the highest, followed by zinc and manganese with $22.11 \mathrm{mg} / \mathrm{kg}$ and $5.10 \mathrm{mg} / \mathrm{kg}$, respectively. Minerals in optimal concentrations are needed for humans and animals to maintain active physiological status. To provide adequate amounts of microelements, the diets in intensive livestock breeding are supplemented with synthetic premixes [60]. Microelement-rich plant-derived materials with natural origin might be a good alternative to currently used mixtures of inorganic salts. This is especially valid for organic agriculture where diet formulation is subjected to strict regulations, which stimulate the inclusion of organically certified ingredients and additives [61]. Ligas et al. [62] reported that laying hens fed diets supplemented with bio-metallic materials produced eggs that had better organoleptic parameters than those laid by hens fed with conventional premixes. The content of lead and cadmium in the SEWS was under the detection level of the method used for analyzes (Table 3). The presence of heavy metals in plants though is variable and highly dependent on soil contamination [63].

Table 3. Selected microelements and heavy metal contents of sunflower meal ethanol-wash solute.

\begin{tabular}{cc}
\hline Component & Content, $\mathbf{m g} / \mathbf{k g}$ \\
\hline Copper (Cu) & 109.36 \\
Iron (Fe) & 259.02 \\
Manganese (Mn) & 5.10 \\
Selenium (Se) & 0.10 \\
Zinc (Zn) & 22.11 \\
Lead (Pb) & $<0.10$ \\
Cadmium (Cd) & $<0.01$ \\
\hline
\end{tabular}

Sunflower meal is one of the few feed ingredients considered a relatively good source of Se [60]. The SEWS, prepared in the current study, contained $0.10 \mathrm{mg} / \mathrm{kg}$ Se (Table 3), which contributed to the overall value of the product. Selenium (Se) is a trace element needed for the proper conformation and functionality of more than 25 proteins [64]. Although it is largely distributed in both animals and plants, Se deficiency is observed in some countries which are mostly associated with the low level of this microelement in soil, and as a consequence in food and feed [65].

\subsection{Antioxidant Properties of SEWS}

Multiple in vitro testing methods (DPPH, FRAP, and hydroxyl radical scavenging activity assay) and solvents (water and $70 \%$ ethanol) were used to evaluate the antioxidant potential of SEWS. Either in 70\% ethanol or water, the SEWS was able to scavenge DPPH radicals (Figure 1). Antiradical activity increased with the increase of concentrations, reaching $52.3 \%$ for SEWS-W and $69 \%$ for SEWS-E at $0.05 \%$. The antioxidant capacity of the latter was not different $(p>0.05)$ from those of the BHT at the same concentration. This finding indicates SEWS as a potential alternative to BHT which is currently used as a synthetic antioxidant agent in the food industry [66]. Interestingly, no significant difference in the antiradical potency of SEWS-E and SEWS-W was observed at concentrations lower than $0.04 \%$ (Figure 1 ). 


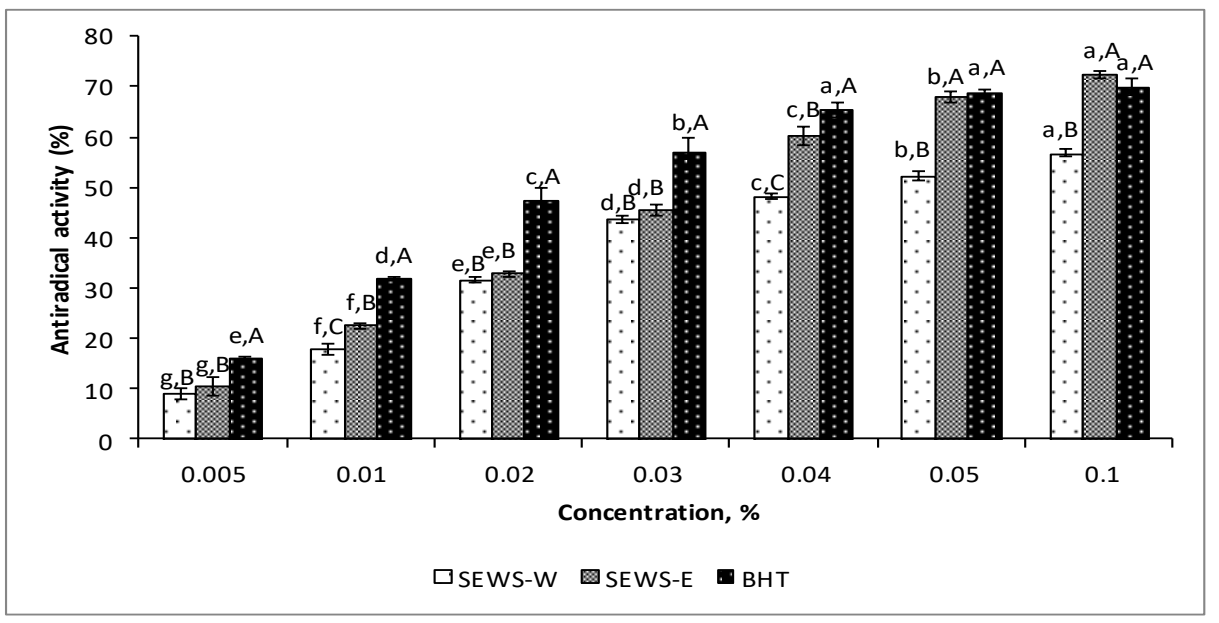

Figure 1. Scavenging effect of sunflower meal ethanol-wash solute dissolved in water (SEWS-W) and in ethanol (SEWS-E) on 2,2-diphenyl-1-picryl hydrazyl (DPPH) radical. ${ }^{\text {a-g }}$ Means of one sample with different concentrations without a common letter differ significantly $(p<0.05)$. ${ }^{\mathrm{A}-\mathrm{C}}$ Means of the three samples with one and the same concentration without a common letter differ significantly $(p<0.05)$. Standard deviations (SD) of the means varied from 0.34 to 3.09 .

No significant difference was established between the FRAP of SEWS-E and SEWS-W as well (Figure 2). The FRAP method is based on the reduction of ferric-tripyridyltriazine $\left(\mathrm{Fe}^{3+}\right.$-TPTZ) complex. Pulido et al. [67] noticed that the reduction of $\mathrm{Fe}^{3+}$ by some phenolic compounds such as caffeic acid, tannic acid, ferulic acid, and gallic acid did not stop in the measurement time frame of the assay i.e., $10 \mathrm{~min}$. Instead, it slowly continued over time, resulting in a gradual increase of the absorption at $593 \mathrm{~nm}$ during $30 \mathrm{~min}$. This might lead potentially to underestimation and low discrimination of the SEWS ferric reducing antioxidant power in water and ethanol, compared to the DPPH method. The presence of bioactive compounds in low concentration and different solubility in water and ethanol might be responsible for the different effects of the sample on FRAP and DPPH results for concentrations higher than $0.04 \%$. Still, the FRAP of the SEWS was approximately 3 -fold higher than that of the ethanol-wash solute obtained from industrial rapeseed meal [12].

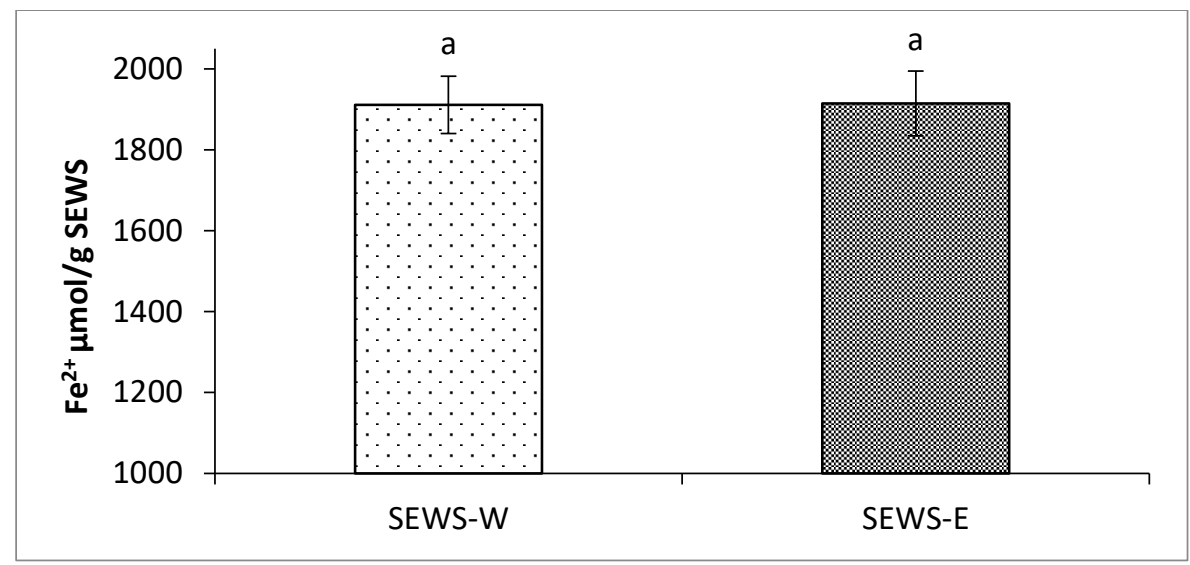

Figure 2. Ferric Reducing Antioxidant Power (FRAP) of sunflower meal ethanol-wash solute. ${ }^{a}$ Means do not differ significantly $(p>0.05)$.

The hydroxyl radical scavenging activity of SEWS-W was dose-dependent as the maximum inhibition value $(52.4 \%$ ) was achieved at $0.1 \%$ (Figure 3 ). For all concentrations studied, from $0.005 \%$ to $0.1 \%$, the SEWS-W exhibited a higher inhibition capacity than mannitol, which was used as a positive control. Water was used as the only solvent in these experiments due to interference of the ethanol with the assay. 


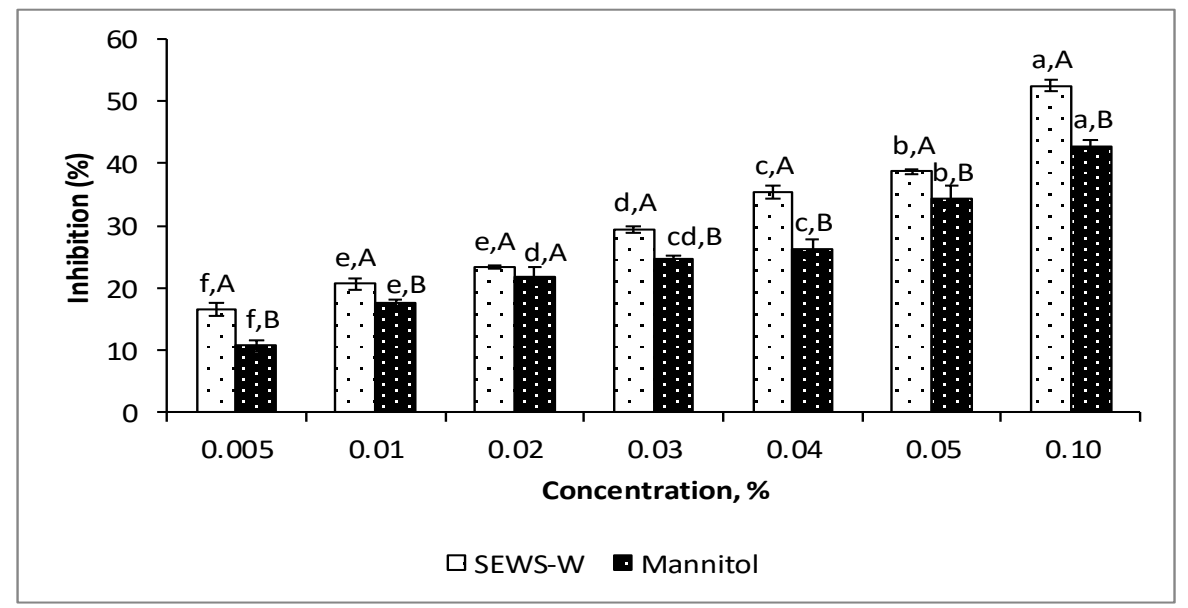

Figure 3. Hydroxyl radical scavenging activity of sunflower meal ethanol-wash solute dissolved in water. ${ }^{a-f}$ Means of one sample with different concentrations without a common letter differ significantly $(p<0.05) .{ }^{\mathrm{A}, \mathrm{B}}$ Means of the two samples with the same concentration without a common letter differ significantly $(p<0.05)$. Standard deviations (SD) of the means varied from 0.27 to 1.98 .

The results obtained from the three types of assays demonstrated approximately three-fold higher antioxidant capacity of the SEWS compared to the ethanol-wash solute prepared similarly from rapeseed meal [12]. Cisneros-Yupanqui et al. [68] reported that the addition of $15 \%$ SEWS to sunflower and soybean oils enhanced their oxidative stability more than that achieved by the supplementation of the same amount of rapeseed meal ethanol-wash solute. Moreover, in the same study for all tested oils (sunflower, soybean, and rapeseed oils), the 5\% SEWS exhibited antioxidant activity index values similar to these of BHT, which imply a plausible replacement of the synthetic antioxidant with a natural one. These observations might be due to the compositional differences in the two products. The SEWS contained a higher amount of total phenols and approximately three-fold higher total flavonoids than the rapeseed meal ethanol-wash solute [12]. Both groups of plant secondary metabolites, phenols, and flavonoids, are potent antioxidants being able to prevent biomolecules including fats, proteins, and DNA from damaging [1]. Another difference that should be noted is in the relative content of phenolic acids and their major constituents, namely chlorogenic and sinapic acid being either present or not in the products. Differences in the phenolic profile of SEWS and rapeseed meal ethanol wash-solute were previously identified by HPLC analyzes as well [69].

Although phenols and flavonoids are the antioxidant compounds in the highest amounts in the SEWS, there might be other molecules in the mixture such as trace elements and proteins that might contribute to the overall antioxidant capacity. The cytosolic defensive ability of copper, zinc, and selenium against reactive oxygen and nitrogen species is well documented [69-71]. Proteins and especially peptides, a product of the hydrolytic cleavage of the proteins, are considered to have high potential as food antioxidants. These molecules inhibit lipid oxidation by neutralization of free radicals, reactive oxygen species, or chelation of pro-oxidative transition metals [72].

The antioxidant properties of the SEWS were analyzed by using three methods differing by their principles to better evaluate the potential applicability of the product. The experiments were conducted in water and ethanol with a clear understanding of the influence of the solvent on the antioxidant capacity of the sample [73,74] and plausible underestimation of the evaluated features. It is highly possible to obtain higher antioxidant activities in other solvents. However, water and ethanol are largely used in the food and nutraceutical industries, and obtained knowledge could be easily transferred to new technologies. In addition, ethanol is generally recognized as safe (GRAS) [75] and is recently reconsidered as a useful extracting agent in "green" technologies $[33,46,47]$. Due to the complexity of the SEWS composition, in vivo model systems could be used to complement 
the acquired knowledge and more completely characterize the antioxidant properties of the product $[76,77]$.

\subsection{Antimicrobial Activity of SEWS}

The SEWS exhibited limited antimicrobial activity (Table 4). Curtobacterium flaccumfaciens PM-YT growth was inhibited the most as the first inhibition zone was observed at $0.313 \mathrm{mg} / \mathrm{mL}$ SWES (Table 5). The product was either weakly active or inactive against the remaining Gram (+) and Gram (-) bacteria. Among screened fungi, the highest inhibition was achieved against Fusarium moniliforme ATCC 38932 with MIC of $0.625 \mathrm{mg} / \mathrm{mL}$ (Table 5). F. moniliforme and C. flaccumfaciens are plant pathogens causing significant economic losses. Regardless of the numerous antimicrobial agents available in the market, the propagation of these microorganisms is difficult to control, especially in organic agriculture where utilization of synthetic pesticides is not acceptable [78]. For comparison, the ethanol-wash solute obtained from rapeseed meal exhibited antifungal activity against all tested fungi including Aspergillus niger ATCC 1015, Aspergillus flavus, Penicillium sp., Rhizopus sp., and Fusarium moniliforme ATCC 38932 with MIC of $0.313 \mathrm{mg} / \mathrm{mL}$ [12]. The authors attributed this effect to glucosinolates in the rapeseed meal ethanol-wash solute which, however, were not present in the SEWS (Tables 1 and 2).

Table 4. Screening of sunflower meal ethanol-wash solute for antimicrobial activity against selected microorganisms.

\begin{tabular}{|c|c|c|c|c|c|c|}
\hline \multirow{3}{*}{ Test Microorganism } & \multicolumn{6}{|c|}{ Zone of Inhibition, $\mathrm{mm}$} \\
\hline & \multicolumn{6}{|c|}{ SEWS Concentration, mg/mL } \\
\hline & 5.0 & 2.5 & 1.25 & 0.625 & 0.313 & 0.156 \\
\hline \multicolumn{7}{|c|}{ Gram $(+)$ bacteria } \\
\hline Bacillus subtilis ATCC 6633 & 0 & 0 & 0 & 0 & 0 & 0 \\
\hline Bacillus cereus & 0 & 0 & 0 & 0 & 0 & 0 \\
\hline Bacillus amyloliquefaciens 4BCL-YT & 8 & 0 & 0 & 0 & 0 & 0 \\
\hline Staphylococcus aureus ATCC 25923 & 0 & 0 & 0 & 0 & 0 & 0 \\
\hline Listeria monocytogenes ATCC 8632 & 0 & 0 & 0 & 0 & 0 & 0 \\
\hline Enterococcus faecalis & 0 & 0 & 0 & 0 & 0 & 0 \\
\hline Micrococcus luteus 2YC-YT & 8 & 0 & 0 & 0 & 0 & 0 \\
\hline Curtobacterium flaccumfaciens PM-YT & 12 & 12 & 10 & 10 & 8 & 0 \\
\hline \multicolumn{7}{|c|}{ Gram $(-)$ bacteria } \\
\hline Salmonella enteritidis & 0 & 0 & 0 & 0 & 0 & 0 \\
\hline Escherichia coli ATCC 8739 & 9 & 8 & 0 & 0 & 0 & 0 \\
\hline Proteus vulgaris ATCC 6380 & 0 & 0 & 0 & 0 & 0 & 0 \\
\hline Pseudomonas aeruginosa ATCC 9027 & 8 & 8 & 0 & 0 & 0 & 0 \\
\hline \multicolumn{7}{|c|}{ Fungi } \\
\hline Candida albicans NBIMCC 74 & 0 & 0 & 0 & 0 & 0 & 0 \\
\hline Saccharomyces cerevisiae & 0 & 0 & 0 & 0 & 0 & 0 \\
\hline Aspergillus niger ATCC 1015 & 10 & 8 & 0 & 0 & 0 & 0 \\
\hline Aspergillus flavus & 8 & 0 & 0 & 0 & 0 & 0 \\
\hline Fusarium moniliforme ATCC 38932 & 12 & 10 & 8 & 8 & 0 & 0 \\
\hline
\end{tabular}

Owing to the high amount of phenols in the SEWS, the low antimicrobial activity was unexpected. It might be due to the composite nature of the material. Multiple constituents of the SEWS might interact with each other, forming complexes with structures and properties differing from single compounds. The antimicrobial activity of the sunflower was mainly attributed to chlorogenic acid, the biological activity of which as a single compound was found higher [79] than in a mixture [80]. Besides, a potential formation of compounds with higher molecular weights might slow the diffusion of the active compounds and decrease their solubility in solid media, thus affecting the size of the zones and, as a whole, the interpretation of results [81]. Although the agar-well diffusion 
method is widely used to screen plant extracts for antimicrobial activity [82], more studies should be conducted to avoid inaccurate conclusions on SEWS antimicrobial properties. Current findings imply a potential significance of the SEWS as an antimicrobial agent which, however, should be further investigated by using other methods and approaches.

Table 5. Minimum inhibitory concentration (MIC) of sunflower meal ethanol-wash solute against the test microorganisms.

\begin{tabular}{cc}
\hline Test Microorganism & Minimum Inhibitory Concentration, mg/mL \\
\hline Gram (+) bacteria & $\mathrm{N}$ \\
\hline Bacillus subtilis ATCC 6633 & $\mathrm{N}$ \\
Bacillus cereus & 5.0 \\
Bacillus amyloliquefaciens 4BCL-YT & $\mathrm{N}$ \\
Staphylococcus aureus ATCC 25923 & $\mathrm{N}$ \\
Listeria monocytogenes ATCC 8632 & $\mathrm{N}$ \\
Enterococcus faecalis & 5.0 \\
Micrococcus luteus 2YC-YT & 0.313 \\
Curtobacterium flaccumfaciens PM-YT & $\mathrm{N}$ \\
\hline Gram (-) bacteria & 2.5 \\
Salmonella enteritidis & $\mathrm{N}$ \\
Escherichia coli ATCC 8739 & 2.5 \\
Proteus vulgaris ATCC 6380 & \\
Pseudomonas aeruginosa ATCC 9027 & $\mathrm{N}$ \\
\hline Fungi & $\mathrm{N}$ \\
Candida albicans NBIMCC 74 & 2.5 \\
Saccharomyces cerevisiae & 5.0 \\
Aspergillus niger ATCC 1015 & 0.625 \\
\hline Aspergillus flavus & \\
\hline
\end{tabular}

$\mathrm{N}$, no zone of inhibition was found.

\section{Conclusions}

SEWS is a novel product composed mainly of carbohydrates and lipids. It also contains biologically active compounds, phenols, and flavonoids, in relatively high amounts, which attribute to the antioxidant and antimicrobial capacity of the SEWS. Initially obtained as a waste of the protein isolate preparation from the sunflower meal, the functional properties of the SEWS turn it into a useful material with versatile application in the food or nutraceutical industries. The antioxidant activity of SEWS in water evaluated by the DPPH method was not different from that of the sample in ethanol up to $0.04 \%$. This is important for the potential application of the SEWS in the food industry where water is the main solvent used. The SEWS demonstrated moderate inhibiting properties against Gram (+) Curtobacterium flaccumfaciens PM-YT and Fusarium moniliforme ATCC 38932, which are economically significant plant pathogens. Further modification steps toward enhancement of the SEWS antimicrobial activity could allow the use of the product as an antimicrobial agent. Being a step from a scheme for a complete valorization of the sunflower meal, the SEWS preparation and characteristic profile demonstrated the feasibility of adding value to byproducts generated by the food industry. It corresponds to the enhanced customers' demand for natural product use and the worldwide need for gentle care to the environment.

Author Contributions: Conceptualization, V.I.C.; Methodology, P.I., I.G.I., H.K. and I.N.D. and Y.T.; Software, P.I.; Formal Analysis, P.I., I.G.I., H.K., I.N.D. and Y.T.; Data Curation, V.I.C.; WritingOriginal Draft Preparation, V.I.C.; Writing-Review \& Editing, P.I., I.G.I., H.K. and I.N.D. and Y.T.; Supervision, V.I.C.; Project Administration, V.I.C.; Funding Acquisition, V.I.C. All authors have read and agreed to the published version of the manuscript. 
Funding: This research was funded by the Bulgarian National Science Fund, project No. КП-06H37/21 "An integrated approach for efficient utilization of by-products of vegetable oil-producing industry: Sunflower and rapeseed meals".

Institutional Review Board Statement: Not applicable.

Informed Consent Statement: Not applicable.

Data Availability Statement: Data are available on request.

Acknowledgments: The authors are grateful to the Department of Microbiology, The University of Food Technologies-Plovdiv, Bulgaria for providing test microorganisms, to Biser Oliva AD (Stara Zagora, Bulgaria) and Oliva AD (Polski Trambesh, Bulgaria) for providing sunflower and rapeseed meals, respectively.

Conflicts of Interest: The authors declare no conflict of interest.

\section{References}

1. Adeleke, B.S.; Babalola, O.O. Oilseed crop sunflower (Helianthus annuus) as a source of food: Nutritional and health benefits. Food Sci. Nutr. 2020, 8, 4666-4684. [CrossRef]

2. Zhou, Y.; Zhao, W.; Lai, Y.; Zhang, B.; Zhang, D. Edible plant oil: Global status, health issues, and perspectives. Front. Plant Sci. 2020, 11, 1315. [CrossRef]

3. Yegorov, B.; Turpurova, T.; Sharabaeva, E.; Bondar, Y. Prospects of using by-products of sunflower oil production in compound feed industry. Food Sci. Technol. 2019, 13, 106-113. [CrossRef]

4. Ancuța, P.; Sonia, A. Oil press-cakes and meals valorization through circular economy approaches: A review. Appl. Sci. 2020, 10, 7432. [CrossRef]

5. Lević, J.D.; Sredanović, S.A.; Đuragić, O.M. Sunflower meal protein as a feed for broilers. Acta Period. Technol. 2005, 36, 3-10. [CrossRef]

6. de Oliveira Filho, J.G.; Egea, M.B. Sunflower seed byproduct and its fractions for food application: An attempt to improve the sustainability of the oil process. J. Food Sci. 2021, 86, 1497-1510. [CrossRef]

7. Baiano, A. Recovery of biomolecules from food wastes-A review. Molecules 2014, 19, 14821-14842. [CrossRef]

8. Liu, Y.; Zhou, M.; Liu, M. A survey of nutrients and toxic factors in commercial rapeseed meal in China and evaluation of detoxificationby water extraction. Anim. Feed Sci. Technol. 1994, 45, 257-270. [CrossRef]

9. Laguna, O.; Guyot, S.; Yu, X.; Broudiscou, L.P.; Chapoutot, P.; Solé-Jamault, V.; Anton, M.; Quinsac, A.; Sicaire, A.G.; Fine, F.; et al. The PHENOLEO project or how to separate and add-value to phenolic compounds present in rapeseed and sunflower meals. OCL 2020, 27, 61. [CrossRef]

10. Kalaydzhiev, H.; Ivanova, P.; Stoyanova, M.; Pavlov, A.; Rustad, T.; Silva, C.L.; Chalova, V.I. Valorization of rapeseed meal: Influence of ethanol antinutrients removal on protein extractability, amino acid composition and fractional profile. Waste Biomass Valor. 2020, 11, 2709-2719. [CrossRef]

11. Kalaydzhiev, H.; Georgiev, R.; Ivanova, P.; Stoyanova, M.; Silva, C.L.; Chalova, V.I. Enhanced solubility of rapeseed meal protein isolates prepared by sequential isoelectric precipitation. Foods 2020, 9, 703. [CrossRef]

12. Georgiev, R.; Ivanov, I.G.; Ivanova, P.; Tumbarski, Y.; Kalaydzhiev, H.; Dincheva, I.N.; Badjakov, I.K.; Chalova, V.I. Phytochemical profile and bioactivity of industrial rapeseed meal ethanol-wash solutes. Waste Biomass Valor. 2021, 12, 5051-5063. [CrossRef]

13. Gandova, V.; Ivanova, P.; Kalaydzhiev, H.; Perifanova-Nemska, M.; Chalova, V.I. Dissolution and surface tension properties of ethanol-wash solute obtained from industrial sunflower meal. Biointerface Res. Appl. Chem. 2021, 11, 11284-11292. [CrossRef]

14. Dubois, M.; Gilles, K.A.; Hamilton, J.K.; Rebers, P.T.; Smith, F. Colorimetric method for determination of sugars and related substances. Anal. Chem. 1956, 28, 350-356. [CrossRef]

15. Hill, J.B.; Kessler, G. An automated determination of glucose utilizing a glucose oxidase-peroxidase system. J. Lab. Clin. Med. 1961, 57, 970-980.

16. Bligh, E.G.; Dyer, W.J. A rapid method of total lipid extraction and purification. Can. J. Biochem. 1959, 37, 911-917. [CrossRef]

17. Bradford, M. A rapid and sensitive for the quantitation of microgram quantities of protein utilizing the principle of protein-dye binding. Anal. Biochem. 1976, 72, 248-254. [CrossRef]

18. International Association for Cereal Science and Technology. 104/1: Determination of Ash in Cereals and Cereal Products. Approved 1960, Revised 1990; International Association for Cereal Science and Technology: Vienna, Austria, 1990.

19. Petkova, N.; Ivanov, I.; Denev, P.; Pavlov, A. Bioactive substance and free radical scavenging activities of flour from Jerusalem artichoke (Helianthus tuberosus L.) tubers-A comparative study. Turk. J. Agric. Nat. Sci. 2014, 1, 1773-1778.

20. Kivrak, I.; Duru, M.E.; Öztürk, M.; Mercan, N.; Harmandar, M.; Topçu, G. Antioxidant, anticholinesterase and antimicrobial constituents from the essential oil and ethanol extract of Salvia Potentillifolia. Food Chem. 2009, 116, 470-479. [CrossRef]

21. ISO 11885:2007. Water Quality—Determination of Selected Elements by Inductively Coupled Plasma Optical Emission Spectrometry (ICP-OES). Available online: http:/ / www.iso.org/iso/catalogue_detail.htm?csnumber=36250 (accessed on 6 January 2019).

22. BDS 11374. Available online: https://bds-bg.org/ (accessed on 16 February 2019). 
23. Roessner, U.; Wagner, C.; Kopka, J.; Trethewey, R.N.; Willmitzer, L. Simultaneous analysis of metabolites in potato tuber by gas chromatography-mass spectrometry. Plant J. 2000, 23, 131-142. [CrossRef]

24. Ivanov, I.; Vrancheva, R.Z.; Marchev, A.S.; Petkova, N.T.; Aneva, I.Y.; Denev, P.P.; Georgieva, V.G.; Pavlov, A.I. Antioxidant activities and phenolic compounds in Bulgarian Fumaria species. Int. J. Curr. Microbiol. Appl. Sci. 2014, 3, $296-306$.

25. Irshad, M.; Zafaryab, M.; Singh, M.; Rizvi, M. Comparative analysis of the antioxidant activity of Cassia fistula extracts. Int. J. Med. Chem. 2012, 2012, 15712. [CrossRef]

26. Yan, X.; Nagata, T.; Fan, X. Antioxidative activities in some common seaweeds. Plant Foods Hum. Nutr. 1998, 52, $253-262$. [CrossRef]

27. Roy, S.; Hazra, B.; Mandal, N.; Chaudhuri, T.K. Assessment of the antioxidant and free radical scavenging activities of methanolic extract of Diplazium esculentum. Int. J. Food Prop. 2013, 16, 1351-1370. [CrossRef]

28. Aljohi, A.; Matou-Nasri, S.; Ahmed, N. Antiglycation and antioxidant properties of Momordica charantia. PLoS ONE 2016, 11, e0159985. [CrossRef]

29. Tumbarski, Y.; Deseva, I.; Mihaylova, D.; Stoyanova, M.; Krastev, L.; Nikolova, R.; Yanakieva, V.; Ivanov, I. Isolation, characterization and amino acid composition of a bacteriocin produced by Bacillus methylotrophicus strain BM47. Food Technol. Biotechnol. 2018, 56, 546-552. [CrossRef]

30. Gonelimali, F.D.; Lin, J.; Miao, W.; Xuan, J.; Charles, F.; Chen, M.; Hatab, S.R. Antimicrobial properties and mechanism of action of some plant extracts against food pathogens and spoilage microorganisms. Front. Microbiol. 2018, 9, 1639. [CrossRef]

31. Singh, Y.; Farooq, A.; Raza, A.; Mahmood, M.A.; Jain, S. Sustainability of a non-edible vegetable oil-based bio-lubricants for automotive applications: A review. Process. Saf. Environ. Prot. 2017, 111, 701-713. [CrossRef]

32. Bai, Y.; Zhai, Y.; Ji, C.; Zhang, T.; Chen, W.; Shen, X.; Hong, J. Environmental sustainability challenges of China's edible vegetable oil industry: From farm to factory. Resour. Conserv. Recycl. 2021, 170, 105606. [CrossRef]

33. Baümler, E.R.; Carrín, M.E.; Carelli, A.A. Extraction of sunflower oil using ethanol as solvent. J. Food Eng. 2016, 178, 190-197. [CrossRef]

34. Balto, A.S.; Lapis, T.J.; Silver, R.K.; Ferreira, A.J.; Beaudry, C.M.; Lim, J.; Penner, M.H. On the use of differential solubility in aqueous ethanol solutions to narrow the DP range of food-grade starch hydrolysis products. Food Chem. 2016, 197, 872-880. [CrossRef]

35. Nyyssölä, A.; Ellilä, S.; Nordlund, E.; Poutanen, K. Reduction of FODMAP content by bioprocessing. Trends Food Sci. Technol. 2020, 99, 257-272. [CrossRef]

36. Bonestroo, M.H.; Kusters, B.J.M.; De Wit, J.C.; Rombouts, F.M. Glucose and sucrose fermenting capacity of homofermentative lactic acid bacteria used as starters in fermented salads. Int. J. Food Microbiol. 1992, 15, 365-376. [CrossRef]

37. Naher, U.A.; Radziah, O.; Halimi, M.S.; Shamsuddin, Z.H.; Razi, I.M. Specific growth rate and carbon sugar consumption of diazotrophs isolated from rice rhizosphere. J. Biol. Sci. 2008, 8, 1008-1014. [CrossRef]

38. Molina-Ramírez, C.; Castro, M.; Osorio, M.; Torres-Taborda, M.; Gómez, B.; Zuluaga, R.; Gómez, C.; Gañán, P.; Rojas, O.J.; Castro, C. Effect of different carbon sources on bacterial nanocellulose production and structure using the low $\mathrm{pH}$ resistant strain Komagataeibacter medellinensis. Materials 2017, 10, 639. [CrossRef]

39. Gao, M.; Ploessl, D.; Shao, Z. Enhancing the co-utilization of biomass-derived mixed sugars by yeasts. Front. Microbiol. 2019, 9, 3264. [CrossRef]

40. Abdel-Rahman, M.A.; Hassan, S.E.-D.; Alrefaey, H.M.A.; Elsakhawy, T. Efficient co-utilization of biomass-derived mixed sugars for lactic acid production by Bacillus coagulans Azu-10. Fermentation 2021, 7, 28. [CrossRef]

41. Msomi, N.Z.; Erukainure, O.L.; Islam, M. Suitability of sugar alcohols as antidiabetic supplements: A review. J. Food Drug Anal. 2021, 29, 1-14. [CrossRef]

42. Ibrahim, O.O. Sugars alcohols: Chemical structures, manufacturing, properties and applications. EC Nutr. 2016, 6, 817-824. [CrossRef]

43. Wölnerhanssen, B.K.; Meyer-Gerspach, A.C.; Beglinger, C.; Islam, M.S. Metabolic effects of the natural sweeteners xylitol and erythritol: A comprehensive review. Crit. Rev. Food Sci. Nutr. 2020, 60, 1986-1998. [CrossRef]

44. Rice, T.; Zannini, E.; Arendt, E.K.; Coffey, A. A review of polyols-biotechnological production, food applications, regulation, labeling and health effects. Crit. Rev. Food Sci. Nutr. 2020, 60, 2034-2051. [CrossRef]

45. Kõljalg, S.; Smidt, I.; Chakrabarti, A.; Bosscher, D.; Mändar, R. Exploration of singular and synergistic effect of xylitol and erythritol on causative agents of dental caries. Sci. Rep. 2020, 10, 6297. [CrossRef]

46. Citeau, M.; Regis, J.; Carré, P.; Fine, F. Value of hydroalcoholic treatment of rapeseed for oil extraction and protein enrichment. OCL 2019, 26, 1. [CrossRef]

47. Rodriguez, L.M.; Fernández, M.B.; Pérez, E.E.; Crapiste, G.H. Performance of green solvents in the extraction of sunflower oil from enzyme-treated collets. Eur. J. Lipid Sci. Technol. 2021, 123, 2000132. [CrossRef]

48. Harun, M. Fatty acid composition of sunflower in 31 inbreed and 28 hybrids. Biomed. J. Sci. Tech. Res. 2019, 16, 12032-12038. [CrossRef]

49. Virsangbhai, C.K.; Goyal, A.; Tanwar, B.; Sihag, M.K. Potential health benefits of conjugated linoleic acid: An important functional dairy ingredient. Eur. J. Nutr. Food Saf. 2020, 11, 200-213. [CrossRef] 
50. Khanra, A.; Srivastava, M.; Rai, M.P.; Prakash, R. Application of unsaturated fatty acid molecules derived from microalgae toward mild steel corrosion inhibition in $\mathrm{HCl}$ solution: A novel approach for metal-inhibitor association. ACS Omega 2018, 3, 12369-12382. [CrossRef]

51. Hassabo, A.G.; Sharaawy, S.; Mohamed, A.L. Unsaturated fatty acids based materials as auxiliaries for printing and finishing of cellulosic fabrics. Biointerface Res. Appl. Chem. 2019, 9, 4284-4291. [CrossRef]

52. Žilić, S.; Barać, M.; Pešić, M.; Crevar, M.; Stanojević, S.; Nišavić, A.; Saratlić, G.; Tolimir, M. Characterization of sunflower seed and kernel proteins. Helia 2010, 33, 103-114. [CrossRef]

53. Holeček, M. Branched-chain amino acids in health and disease: Metabolism, alterations in blood plasma, and as supplements. Nutr. Metab. 2018, 15, 1-12. [CrossRef] [PubMed]

54. Taha, F.S.; Mohamed, G.F.; Mohamed, S.H.; Mohamed, S.S.; Kamil, M.M. Optimization of the extraction of total phenolic compounds from sunflower meal and evaluation of the bioactivities of chosen extracts. Am. J. Food Technol. 2011, 6, 1002-1020. [CrossRef]

55. Laguna, O.; Odinot, E.; Bisotto, A.; Barea, B.; Villeneuve, P.; Sigoillot, J.C.; Record, E.; Faulds, C.B.; Fine, F.; Lesage-Meessen, L.; et al. Release of phenolic acids from sunflower and rapeseed meals using different carboxylic esters hydrolases from Aspergillus niger. Ind. Crops Prod. 2019, 139, 111579. [CrossRef]

56. Jia, W.; Kyriakopoulou, K.; Roelofs, B.; Ndiaye, M.; Vincken, J.P.; Keppler, J.K.; van Der Goot, A.J. Removal of phenolic compounds from de-oiled sunflower kernels by aqueous ethanol washing. Food Chem. 2021, 362, 130204. [CrossRef] [PubMed]

57. Selamoglu, Z.; Sevindik, M.; Bal, C.; Ozaltun, B.; Sen, I.; Pasdaran, A. Antioxidant, antimicrobial and DNA protection activities of phenolic content of Tricholoma virgatum (Fr.) P. Kumm. Biointerface Res. Appl. Chem. 2020, 10, 5500-5506. [CrossRef]

58. Meng, S.; Cao, J.; Feng, Q.; Peng, J.; Hu, Y. Roles of chlorogenic acid on regulating glucose and lipids metabolism: A review. Evid. Based Complement. Alternat. Med. 2013, 2013, 801457. [CrossRef]

59. Govindharaj, D.; Nachimuthu, S.; Gonsalves, D.F.; Kothandan, R.; Dhurai, B.; Rajamani, L.; Ramakrishana, S. Molecular docking analysis of chlorogenic acid against matrix metalloproteinases (MMPs). Biointerface Res. Appl. Chem. 2020, 10, 6865-6873. [CrossRef]

60. Drinceanu, D.; Luca, I.; Julean, C.; Ştef, L.; Mihai, A.; Simiz, E.; Gherasim, V.; Sofian, D. Mineral content of the main feed ingredients used in poultry biological farms. Sci. Papers Anim. Sci. Biotech. 2010, 43, 42-46.

61. Chalova, V.I.; Ricke, S.C. Organic animal nutrition and feed supplementations. In Organic Meat Production and Processing; Ricke, S.C., van Loo, E.J., Johnson, M.G., O’Bryan, C.A., Eds.; John Wiley \& Sons Inc.: Hoboken, NJ, USA, 2012; pp. 157-1758. ISBN 9780813821269. [CrossRef]

62. Ligas, B.; Izydorczyk, G.; Mikula, K.; Skrzypczak, D.; Konkol, D.; Korczyński, M.; Witek-Krowiak, A.; Chojnacka, K. Valorization of post-extraction residues-analysis of the influence of new feed additives with micronutrients on eggs quality parameters. Poult. Sci. 2021, 100, 101416. [CrossRef]

63. Wuana, R.A.; Okieimen, F.E. Heavy metals in contaminated soils: A review of sources, chemistry, risks and best available strategies for remediation. Int. Sch. Res. Notices 2011, 2011, 402647. [CrossRef]

64. D'Amato, R.; Regni, L.; Falcinelli, B.; Mattioli, S.; Benincasa, P.; Dal Bosco, A.; Pacheco, P.; Proietti, P.; Troni, E.; Santi, C.; et al. Current knowledge on selenium biofortification to improve the nutraceutical profile of food: A comprehensive review. J. Agric. Food Chem. 2020, 68, 4075-4097. [CrossRef]

65. Kipp, A.P.; Strohm, D.; Brigelius-Flohé, R.; Schomburg, L.; Bechthold, A.E.; Leschik-Bonnet, E.; Heseker, H. Revised reference values for selenium intake. J. Trace Elem. Med. Biol. 2015, 32, 195-199. [CrossRef]

66. Kebede, M.; Admassu, S. Application of antioxidants in food processing industry: Options to improve the extraction yields and market value of natural products. Adv. Food Tech. Nutr. Sci. 2019, 5, 38-49. [CrossRef]

67. Pulido, R.; Bravo, L.; Saura-Calixto, F. Antioxidant activity of dietary polyphenols as determined by a modified ferric reducing/antioxidant power assay. J. Agric. Food Chem. 2000, 48, 3396-3402. [CrossRef] [PubMed]

68. Cisneros-Yupanqui, M.; Chalova, V.I.; Kalaydzhiev, H.R.; Mihaylova, D.; Krastanov, A.I.; Lante, A. Preliminary characterisation of wastes generated from the rapeseed and sunflower protein isolation process and their valorisation in delaying oil oxidation. Food Bioprocess Technol. 2021, 14, 1962-1971. [CrossRef]

69. Klotz, L.O.; Kröncke, K.D.; Buchczyk, D.P.; Sies, H. Role of copper, zinc, selenium and tellurium in the cellular defense against oxidative and nitrosative stress. J. Nutr. 2003, 133, 1448S-1451S. [CrossRef] [PubMed]

70. Wacewicz, M.; Socha, K.; Soroczyńska, J.; Niczyporuk, M.; Aleksiejczuk, P.; Ostrowska, J.; Borawska, M.H. Selenium, zinc, copper, $\mathrm{Cu} / \mathrm{Zn}$ ratio and total antioxidant status in the serum of vitiligo patients treated by narrow-band ultraviolet-B phototherapy. $J$. Dermatol. Treat. 2018, 29, 190-195. [CrossRef] [PubMed]

71. Socha, K.; Klimiuk, K.; Naliwajko, S.K.; Soroczyńska, J.; Puścion-Jakubik, A.; Markiewicz-Żukowska, R.; Kochanowicz, J. Dietary habits, selenium, copper, zinc and total antioxidant status in serum in relation to cognitive functions of patients with Alzheimer's disease. Nutrients 2021, 13, 287. [CrossRef]

72. Elias, R.J.; Kellerby, S.S.; Decker, E.A. Antioxidant activity of proteins and peptides. Crit. Rev. Food Sci. Nutr. 2008, 48, 430-441. [CrossRef] [PubMed]

73. Zhou, K.; Yu, L. Effects of extraction solvent on wheat bran antioxidant activity estimation. Lebensm. Wiss. Technol. 2004, 37, 717-721. [CrossRef] 
74. Kerchev, P.; Ivanov, S. Influence of extraction techniques and solvents on the antioxidant capacity of plant material. Biotechnol. Biotechnol. Equip. 2008, 22, 556-559. [CrossRef]

75. Center for Food Safety and Applied Nutrition (CFSAN). 2007. Available online: https://www.fda.gov/about-fda/fdaorganization/center-food-safety-and-applied-nutrition-cfsan (accessed on 18 January 2008).

76. Merghem, M.; Dahamna, S.; Khennouf, S. In vivo antioxidant activity of Ruta montana L. Extracts J. Mater. Environ. Sci. 2019, 10, 470-477.

77. Moretton, C.; Gouttefangeas, C.; Dubois, C.; Tessier, F.J.; Fradin, C.; Prost-Camus, E.; Prost, M.; Haumont, M.; Nigay, H. Investigation of the antioxidant capacity of caramels: Combination of laboratory assays and C. elegans model. J. Funct. Foods 2021, 78, 104308. [CrossRef]

78. Osdaghi, E.; Young, A.J.; Harveson, R.M. Bacterial wilt of dry beans caused by Curtobacterium flaccumfaciens pv. flaccumfaciens: A new threat from an old enemy. Mol. Plant Pathol. 2020, 21, 605-621. [CrossRef] [PubMed]

79. Fu, S.; Wu, C.; Wu, T.; Yu, H.; Yang, S.; Hu, Y. Preparation and characterisation of chlorogenic acid-gelatin: A type of biologically active film for coating preservation. Food Chem. 2017, 221, 657-663. [CrossRef] [PubMed]

80. Alexandrino, T.D.; da Silva, M.G.; Ferrari, R.A.; Ruiz, A.L.T.G.; Duarte, R.M.T.; Simabuco, F.M.; Bezerra, R.M.N.; Pacheco, M.T.B. Evaluation of some in vitro bioactivities of sunflower phenolic compounds. Curr. Res. Nutr. Food Sci. 2021, 4, 662-669. [CrossRef] [PubMed]

81. Bonev, B.; Hooper, J.; Parisot, J. Principles of assessing bacterial susceptibility to antibiotics using the agar diffusion method. J. Antimicrob. Chemother. 2008, 61, 1295-1301. [CrossRef]

82. Valgas, C.; Souza, S.M.D.; Smânia, E.F.; Smânia, A., Jr. Screening methods to determine antibacterial activity of natural products. Braz. J. Microbiol. 2007, 38, 369-380. [CrossRef] 